\title{
Ovarian Cancer TNM Finding v6
}

National Cancer Institute

\section{Source}

National Cancer Institute. Ovarian Cancer TNM Finding v6. NCI Thesaurus. Code C60887.

A finding about one or more characteristics of ovarian cancer, following the rules of the

TNM AJCC v6 classification system. 